\title{
Omega 3 fatty acids, gestation and pregnancy outcomes
}

\author{
Elvira Larqué ${ }^{*}$, Alfonso Gil-Sánchez ${ }^{2}$, María Teresa Prieto-Sánchez ${ }^{2}$ and Berthold Koletzko ${ }^{3}$ \\ ${ }^{1}$ Department of Physiology, Faculty of Biology, University of Murcia, Murcia, Spain \\ ${ }^{2}$ Service of Gynecology and Obstetrics, Virgen de la Arrixaca Hospital, Murcia, Spain \\ ${ }^{3}$ Dr. von Haunersches Kinderspital, Ludwig-Maximilians University, Munich, Germany
}

\section{Abstract}

Pregnancy is associated with a reduction in maternal serum docosahexaenoic acid (DHA, 22:6 n-3) percentage and its possible depletion in the maternal store. Since the synthesis of long chain polyunsaturated fatty acids (LCPUFA) in the fetus and placenta is low, both the maternal LCPUFA status and placental function are critical for their supply to the fetus. Maternal supplementation with DHA up to $1 \mathrm{~g} / \mathrm{d}$ or $2.7 \mathrm{~g} \mathrm{n}-3$ LCPUFA did not have any harmful effect. DHA supplementation in large studies slightly the enhanced length of gestation (by about 2 days), which may increase the birth weight by about $50 \mathrm{~g}$ at delivery. However no advice can be given on their general using to avoid preterm deliveries in low or high risk pregnancies. Several studies, but not all, reported improvements of the offspring in some neurodevelopmental tests as a result of DHA supplementation during gestation, or, at least, positive relationships between maternal or cord serum DHA percentages and cognitive skills in young children. The effect seems more evident in children with low DHA proportions, which raises the question of how to identify those mothers who might have a poor DHA status and who could benefit from such supplementation. Most studies on the effects of n-3 LCPUFA supplementation during pregnancy on maternal depression were judged to be of low-to-moderate quality, mainly due to small sample sizes and failure to adhere to Consolidated Standards of Reporting Trials guidelines. In contrast, the effects of n-3 LCPUFA supplementation on reducing allergic diseases in offspring are promising.

\section{Key words: fatty acids: DHA: n-3 LC-PUFA: birth weight: length of gestation: neurodevelopment: systematic review}

Numerous observational studies agree that fatty acid concentration in maternal plasma increases during pregnancy as a direct consequence of physiological gestational hyperlipidemia. Plasma triglyceride levels rise markedly during pregnancy whereas the increase in the other lipid fractions is more moderate $^{(1,2)}$. Phospholipids (PL) are the richest source of polyunsaturated fatty acids (PUFA); during pregnancy, the increment observed for docosahexaenoic acid (DHA, 22:6 n-3) concentration was the highest for all PUFA in both maternal plasma $\mathrm{PL}^{(3,4)}$ and erythrocytes ${ }^{(5)}$. The improved absolute maternal DHA status in plasma PL can not be explained simply by the modification of dietary habits, and the most accepted hypothesis is the enhanced mobilization of DHA from the maternal adipose tissue depots, although an increase in the activity of the enzymes involved in their synthesis in the mother can not be excluded ${ }^{(3)}$. The placenta also partly regulates the mobilization of fatty acids from adipose tissue through leptin secretion to the maternal and fetal circulation $^{(6)}$, although leptin resistance arises near the end of pregnancy.

Despite the increase in the absolute concentrations, the relative amounts of the fatty acids show a different pattern; several studies reported a continuous decline from the first trimester until delivery in the percentage of DHA in maternal plasma
PL and erythrocytes ${ }^{(3,7)}$, as well as in total plasma ${ }^{(7,8)}$, respect to the total fatty acid content; in addition, a reduction in the overall functional essential fatty acid (EFA) status in maternal plasma PL, reflected by the ratio between essential n-3 plus n-6 and the non-essential n-7 plus n-9 unsaturated fatty ${ }^{(3,9)}$, might reflect the mother's inability to mobilize adequate amounts of long-chain polyunsaturated fatty acids (LCPUFA) for optimal fetal development. These observations were consistent across populations selected from five different countries despite the variation in maternal EFA status between countries $^{(9)}$. The high prenatal accumulation in the fetal brain of DHA during the third trimester of pregnancy ${ }^{(10,11)}$, the selective and preferential maternal-fetal transfer of LCPUFA across the placenta ${ }^{(12-18)}$ and the low desaturase activity in both placenta ${ }^{(19)}$ and fetal liver ${ }^{(20)}$ could explain this depletion of LCPUFA in the maternal compartment. In recent years, great attention has turned to considering whether low DHA intakes in pregnant women may achieve an optimal central nervous system development of the fetus ${ }^{(21)}$.

Several studies pointed to an association between the percentage of maternal plasma DHA during gestation and the development of cognitive functions in the neonate. The previous DHA status of the mother, the bioavalilability and dose of LCPUFA used in the maternal supplements, and the

*Corresponding author: Elvira Larqué, fax 0034-868883963, email elvirada@um.es 
functionality of the placenta could affect the fetal levels of LCPUFA and their effect on neurodevelopment. Maternal DHA supplementation during pregnancy significantly increased maternal DHA percentages at delivery ${ }^{(22-29)}$, while cord blood DHA proportions increased in many of these studies ${ }^{(22,27)}$ but not in all ${ }^{(8,30)}$. The association between maternal plasma DHA status, the dietary intake of DHA during gestation, and the development of cognitive functions in the neonate and thereafter in the child has been addressed in several human trials (Table 1). Here, we discuss such studies and the potential roles of LCPUFA supplementation during pregnancy under the perspective of preventive nutrition.

The primary aim of this systematic review was to evaluate the effects of maternal n-3 LCPUFA supplementation during pregnancy on birth outcome (gestational length, birth weight, birth length) as well as on the development of visual and other neural functions in the offspring. The secondary aim was concerned the effects of n-3 LCPUFA supplementation during pregnancy on biochemical markers related with the immunological status in the mother or neonate as well as its influence on symptoms of maternal depression.

\section{Methods}

This paper represents a descriptive transversal study of the results obtained from bibliographic research by means of a systematic review. The selection of the articles was done following the defined inclusion and exclusion criteria.
Inclusion criteria: The existence of any registry system of data related to omega-3 fatty acids and pregnancy. We limited the search to Randomized Controlled Trials and Humans. The participants should be healthy pregnant women receiving any n-3 LCPUFA supplementation during pregnancy or pregnancy + lactation. The studies must have come from original articles published by peer-review journals.

Exclusion criteria: Studies on n-3 LCPUFA supplementation that started after delivery in children or mothers. Articles available only in abstract form. Papers not written in English, Spanish, French or German language.

\section{Descriptors used}

The cut-off date for papers was $1^{\text {st }}$ March 2011. The study of the hierarchical structure of the Thesaurus "Medical Subject Heading Terms" (MeSH) considered appropriate the following descriptors:

"Omega-3 fatty acids"[MeSH]

"Pregnancy"[MeSH]

The most important biomedical databases where consulted (e.g. MEDLINE, The Cochrane Library, LILACS and ISI Web of Sciences).

\section{Search equations}

"Omega-3 fatty acids and Pregnancy". Limits Activated: Humans, Randomized Controlled Trial.

Table 1. Randomized controlled trials of $n-3$ LCPUFA supplementation in healthy pregnancies on birth outcomes

\begin{tabular}{|c|c|c|c|c|}
\hline Study & Participants & Daily Dose & Duration & Primary functional outcome \\
\hline $\begin{array}{l}\text { DOMINO study } \\
\text { Makrides et al. } 2010^{(34)}\end{array}$ & 2399 & $0.8 \mathrm{~g} \mathrm{DHA}+0.1 \mathrm{~g} \mathrm{EPA}$ & Week 22 to delivery & $\begin{array}{l}\text { Longer gestation and increased } \\
\text { birth weight }\end{array}$ \\
\hline \multirow{2}{*}{$\begin{array}{l}\text { POSGRAD study } \\
\text { Ramakrishan et al. } 2010^{(35)} \\
\text { Stein et al. } 2010^{(78)}\end{array}$} & 370 & 400mg DHA & Week 18 to delivery & \\
\hline & & & & $\begin{array}{l}\text { In primigravid, higher birth weight and } \\
\text { head circumferenceGreater length of } \\
\text { chidren at } 18 \text { months }\end{array}$ \\
\hline Bergman et al. $2007^{(79)}$ & 144 & 200mg DHA & Week $21-3$ months & Gestational length, birth weight or \\
\hline Bergman et al. 2008 ${ }^{(22)}$ & & FOS & post-delivery & length (n.s) \\
\hline & & Vit/Min & & Reduced BMI at 21 months \\
\hline Innis and Friesen $2008^{(21)}$ & 135 & $400 \mathrm{mg}$ DHA & Week 16 to delivery & $\begin{array}{l}\text { Gestational length, birth weight } \\
\text { or length (n.s.) }\end{array}$ \\
\hline Danish Cohort & & $1.1 \mathrm{~g} \mathrm{DHA}+1.6 \mathrm{~g}$ EPA & Week 30 to delivery & \\
\hline Olsen et al. $1992^{(36)}$ & 533 & olive oil & & $\begin{array}{l}\text { Longer gestation and increased } \\
\text { birth weight }\end{array}$ \\
\hline Knudsen et al. $2006^{(38)}$ & 3098 & $\begin{array}{l}0.1,0.3,0.7,1.4 \mathrm{~g} \\
2.8 \mathrm{~g} \mathrm{DHA}+\mathrm{EPA}\end{array}$ & week $17-27$ to delivery & Gestational length (n.s) \\
\hline Nuheal study & 195 & $\begin{array}{l}0.5 \mathrm{~g} \text { DHA } \\
\text { 400ug MTHF MTHF + DHA }\end{array}$ & Week 22 to delivery & \\
\hline $\begin{array}{l}\text { Krauss-Etchsmann } \\
\quad \text { et al. } 2007^{(27)}\end{array}$ & & & & Gestational length and birth weight (n.s) \\
\hline $\begin{array}{l}\text { Krauss-Etchsmann } \\
\text { et al. } 2008^{(73)}\end{array}$ & & & & $\begin{array}{l}\text { Reduced Th2 inflammatory cytokines } \\
\text { in cord }\end{array}$ \\
\hline Smuts et al. $2003^{(39)}$ & 53 & $\begin{array}{l}135 \mathrm{mg} \mathrm{DHA} \\
18 \mathrm{mg} \mathrm{DHA}\end{array}$ & Weeks $24-28$ to delivery & $\begin{array}{l}\text { Longer gestation and increased } \\
\text { birth weight }\end{array}$ \\
\hline Helland et al. $2001^{(37)}$ & 341 & $1 \cdot 18 \mathrm{~g} \mathrm{DHA}+0.8 \mathrm{~g} \mathrm{EPA}$ & $\begin{array}{l}\text { Week } 18 \text { to } 3 \text { months } \\
\text { post-delivery }\end{array}$ & $\begin{array}{l}\text { Gestational length and birth weight (n.s) } \\
\text { Greater gestational length } \\
\text { in the highest } \\
\text { cord DHA quartile }\end{array}$ \\
\hline
\end{tabular}

(n.s.) not significant. 
The search made in the different databases provided 88 articles. 80 articles were found in PUBMED, which included all those found in ISI Web of Knowledge. From this bibliographic list of articles, 23 references were included because they fullfilled the inclusion criteria for the primary objectives of this systematic review, while the rest of the documents were only related articles. In addition, 7 articles were found in LILACS but none fell within the inclusion criteria. One Cochrane review was also identified on the effects of maternal n-3 supplementation during pregnancy.

Two different reviewers (EL and AG) evaluated the concordance and discrepancy of the bibliographical search. In Table 1 we present a summary of the following data: Study (first author and year of publication), dose of the n-3 LCPUFA supplements used, time of supplementation, and primary outcome results.

\section{Results and Discussion}

No harmful effect on in the mother or the neonate of $n-3$ LCPUFA supplementation during pregnancy was mentioned. The effect on maternal hypercholesterolemia and hypertriglyceridemia associated with gestation was low; the intake of $4 \mathrm{~g} /$ d fish oil did not alter triacylglycerols, total cholesterol, HDL or LDL-cholesterol during pregnancy in maternal serum or in cord blood compared with the effect of olive oil ${ }^{(31)}$. In addition, no changes were observed in maternal blood pressure ${ }^{(31,32)}$. The consensus recommendations of a panel of experts on behalf of the European Commission is that pregnant women should have an average dietary intake of at least $200 \mathrm{mg}$
DHA/d; intakes of up to $1 \mathrm{~g} / \mathrm{d}$ DHA or $2.7 \mathrm{~g} / \mathrm{d} \mathrm{n}-3$ LCPUFA have been used in randomized clinical trials with no significant adverse effects $^{(33)}$.

Table 1 details the randomized controlled trials until March 2011 that evaluated the effect of n-3 LCPUFA supplementation during pregnancy on birth outcomes; in some of them a follow up of the cohort was reported. In table 2, we included the randomized controlled trials that have evaluated the effect of n-3 LCPUFA supplementation during pregnancy on the neuronal function of the offspring.

\section{Birth Outcomes}

Several studies showed that the maternal intake of n-3 LCPUFA during pregnancy resulted in a slightly longer gestation period and somewhat higher birth weight (Table 1). The sample size is critical for identifying differences in these variables, and large studies such as DOMINO ${ }^{(34)}$, POSGRAD ${ }^{(35)}$, or the Danish Cohort ${ }^{(36)}$ found differences in birth outcomes as a result of $n-3$ supplementation during pregnancy (Table 1). It is important to consider that the higher birth weight reported for n-3 LCPUFA supplementation during pregnancy was probably due to the greater length of these pregnancies, since the differences in birth weight disappeared when using the gestational age as covariable ${ }^{(34)}$. Helland et al $^{(37)}$ did not find differences in the duration of gestation or birth weight in 341 subjects (148 subjects receiving cod liver with $1 \cdot 18 \mathrm{~g}$ DHA $+0 \cdot 8 \mathrm{~g}$ EPA vs. 137 subjects receiving corn oil); nevertheless, when they compared the quartile with the highest concentration of DHA

Table 2. Randomized controlled trials of $n-3$ LCPUFA supplementation during pregnancy on neurodevelopmental function of the offspring

\begin{tabular}{|c|c|c|c|c|}
\hline Study & Participants & Daily dose & Duration & Primary functional outcome \\
\hline $\begin{array}{l}\text { DOMINO study } \\
\text { Makrides et al } 2010^{(34)}\end{array}$ & 2399 & $0.8 \mathrm{~g}$ DHA + 0.1g EPA & Week 22 to delivery & $\begin{array}{l}\text { Language or cognitive skills } \\
\text { at } 18 \text { months (n.s.) } \\
\text { Postpartum maternal depression (n.s.) }\end{array}$ \\
\hline Innis and Friesen $2008^{(21)}$ & 135 & $400 \mathrm{mg}$ DHA & Week 16 to delivery & $\begin{array}{l}\text { More girls in placebo than in the DHA group } \\
\text { had visual acuity } \\
\text { below average at } 2 \text { months }\end{array}$ \\
\hline Judge et $a / 2007 b^{(56)}$ & 29 & $0.214 \mathrm{~g} \mathrm{DHA}$ & Week 24 to delivery & $\begin{array}{l}\text { Problem-solving improved at } 9 \text { months. } \\
\text { Fagan test of infant intelligence (n.s) }\end{array}$ \\
\hline Judge et al 2007a(54) & 30 & & & $\begin{array}{l}\text { Visual acuity (Teller cards) improved } \\
\text { at age } 4 \text { months; } \\
\text { at age } 6 \text { months (n.s) }\end{array}$ \\
\hline Tofail et al 2006 ${ }^{(58)}$ & 249 & $\begin{array}{l}1.2 \mathrm{~g} \text { DHA }+1 \cdot 8 \mathrm{~g} \text { EPA } \\
0.27 \mathrm{~g} \mathrm{ALA}+2 \cdot 3 \mathrm{~g} \text { LA }\end{array}$ & Week 25 to delivery & $\begin{array}{l}\text { Bayley MDI and PDI at age } 10 \text { months (n.s) } \\
\text { Associations by multiple regression analyses }\end{array}$ \\
\hline Colombo et al $2004^{(57)}$ & 77 & $\begin{array}{l}135 \mathrm{mg} \mathrm{DHA} \\
35 \mathrm{mg} \mathrm{DHA}\end{array}$ & Weeks $24-28$ to delivery & $\begin{array}{l}\text { Mental processing improved at } 4 \text { and } \\
6 \text { months but not at } 8 \text { months. } \\
\text { Increase in examining and less distractibility } \\
\text { between age } 1 \text { and } 2 y \text {; attentional } \\
\text { disengagement (n.s.). }\end{array}$ \\
\hline Dunstan et al $2008^{(55)}$ & 72 & $2 \cdot 2 \mathrm{~g} \mathrm{DHA}+1 \cdot 1 \mathrm{~g}$ EPA & Week 20 to delivery & Eye-hand coordination favored at 2.5 years. \\
\hline $\begin{array}{l}\text { Malcolm et al. } 2003 a^{(53)} \\
\text { Malcolm et al. } 2003 b^{(30)}\end{array}$ & 100 & $200 \mathrm{mg}$ fish oil & $\begin{array}{l}\text { Week } 15 \text { to } \\
\text { delivery }\end{array}$ & $\begin{array}{l}\text { Visual acuity (VEP, ERG) (n.s.). } \\
\text { Correlations VEP and ERG with infant DHA }\end{array}$ \\
\hline Helland et al $2001^{(37)}$ & 341 & $1.18 \mathrm{~g} D H A+0.8 \mathrm{~g} E P A$ & $\begin{array}{l}\text { Week } 18 \text { to } \\
3 \text { months post-delivery }\end{array}$ & $\begin{array}{l}\text { EEG and Fagan test (n.s.) during the } 1^{\text {st }} \text { year. } \\
\text { Correlation of EEG on day } 2 \text { and cord DHA }\end{array}$ \\
\hline $\begin{array}{l}\text { Helland et al. } 2003^{(50)} \\
\text { (4-year) }\end{array}$ & 84 & & & $\begin{array}{l}I Q \text { at age } 4 y \text { favoured with DHA } \\
\text { Correlation of IQ with maternal DHA intake }\end{array}$ \\
\hline $\begin{array}{l}\text { Helland et al. } 2008^{(51)} \\
\text { (7-year) }\end{array}$ & 142 & & & $\begin{array}{l}\text { IQ (n.s.). Significant correlation at age } 7 \text { with } \\
\text { maternal DHA during pregnancy }\end{array}$ \\
\hline
\end{tabular}

(n.s.) not significant; VEP, visual evoked potentials; ERG, electroretinogram; EEG, electroencephalography; MDI, mental development score; PDI, psychomotor development score. 
in umbilical plasma phospholipids with the quartile with the lowest concentration of DHA, they found a longer gestational period in the group of babies with higher DHA cord concentration. In addition, Knudsen et al. ${ }^{(38)}$ suggested that the effect of n-3 LCPUFA on the length of gestation could be a "quickacting" effect, since they did not find any association between the intake of n-3 LCPUFA or $\alpha$-linolenic acid and the timing of spontaneous delivery in their study in which a large proportion of the women stopped taking the capsules before they delivered. For smaller studies, limitations in their statistical power for such variables could explain the lack of differences for these parameters $(21,22,27,39)$.

The results on higher birth weight and length of gestation were also confirmed in different meta-analyses about the effects of n-3 LCPUFA supplementation during pregnancy ${ }^{(40-42)}$. Szajewska et $a l^{(41)}$ reported that n-3 LCPUFA supplementation during pregnancy (1278 infants from 6 randomized controlled trials) enhanced the duration of the pregnancy by an average of 1.6 days, and head circumference was also $0.26 \mathrm{~cm}$ greater in the supplemented group. In the Cochrane review ${ }^{(40)}$, covering 6 trials involving 2783 women, marine oil supplementation during pregnancy resulted in a mean gestation that was 2.6 days longer for these subjects than for women allocated to placebo or no treatment, and the birth weight was slightly higher (weight mean difference $47 \mathrm{~g}$, 95\% CI 1-93 g; 3 trials, 2440 women). Recently, Salvig \& Lamont ${ }^{(42)}$ also reported higher birth weight $(71 \mathrm{~g})$ in women who received $n-3$ fatty acids during pregnancy compared with a placebo (3 RCT involving 1187 women), and a longer gestational period ( 4.5 days). However, its effect on the rate of preterm birth is controversial; only Salvig et $a l^{(42)}$ reported a significant reduction of preterm births ( $<37$ weeks) while the reduction of early preterm birth $(<34$ weeks) was found to be significant in two of these meta-analyses ${ }^{(40,42)}$. However, the rate of low birth weight $(<2500 \mathrm{~g})$ was not statistically different in any of the 3 meta-analyses ${ }^{(40-42)}$.

Although the effect of n-3 LCPUFA supplementation in high risk pregnancies is not mainly addressed in this systematic review, the results in this respect are controversial. In a European Multicenter Trial $^{(43)}$ involving women with a preterm delivery history, those randomly assigned to receive an n-3 LCPUFA supplement ( $0.9 \mathrm{~g} \mathrm{DHA}+1.3 \mathrm{~g}$ EPA $)$ had significantly lower rate of recurrent preterm delivery before 37 weeks (mean difference $0.54 \%$, 95\% CI 0.30-0.98) and before 34 weeks. Moreover, in a prospective cohort study in Denmark with 8729 pregnant women, the low consumption of fish was a strong risk factor for preterm delivery and low birth weight $^{(44)}$. However, recently, Harper et al ${ }^{(45)}$ did not report changes in gestational length, birth weight or length in pregnant women receiving 17- $\alpha$-hydroxyprogesterone caproate plus $800 \mathrm{mg} / \mathrm{d}$ DHA $+1 \cdot 2 \mathrm{~g}$ EPA to prevent recurrent preterm birth. In addition, the daily intake of either $3 \mathrm{~g}$ EPA or placebo did not prevent the recurrence of intrauterine growth retardation or pregnancy induced hypertension in 63 subjects with high risk pregnancies. The results of the meta-analyses showed no clear difference in the relative risk of birth before 37 completed weeks in high risk pregnancies ${ }^{(40,46)}$. Thus, using n-3 LCPUFA supplements to reduce the risk of preterm birth, low birth weight or small-for-gestational age is still controversial, although a slight effect remains a possibility.

\section{Effects on visual and cognitive functions}

To date, no meta-analyses on the effect of the maternal intake of n-3 fatty acids during pregnancy on the visual or cognitive functions of the offspring have been published. Two Cochrane reviews are available on the effects of infant formulas supplemented with n-3 LCPUFA after birth in term and preterm babies but this is beyond our scope ${ }^{(47,48)}$.

The available results of the present systematic review suggest some association between early DHA status and cognitive function in infancy and early childhood (Table 2). Helland et al. ${ }^{(37)}$ reported that $1 \cdot 18 \mathrm{~g}$ of DHA supplementation during pregnancy did not change electroencephalogram tests on the second day of life or the results of the Fagan test of intelligence at 27 and 39 weeks of age; however, neonates with mature electroencephalography scores had a higher concentration of DHA in umbilical plasma phospholipids. The Fagan test of infant cognitive function is predictive for IQ at an older age, and is comparable to the Bayley test ${ }^{(49)}$. Since it is more difficult to detect small differences in neurodevelopment early in life with these tests than later on when children are older, these authors are engaged in following up this cohort of children. In fact, at 4 years of age, these authors reported improved results in the Kaufmann ABC test of cognitive development in children from mothers receiving DHA supplements ${ }^{(50)}$, and significant correlations for IQ in the sequential processing at 7 years of age with maternal DHA proportions $^{(51)}$.

Rudimentary forms of various attentional functions are present at birth, but each of the functions exhibits different and apparently dissociable periods of postnatal change during the first years of life. ${ }^{(52)}$. Malcolm et al. demonstrated an association between DHA status of term infants and retinal sensitivity within the first week of life $\mathrm{f}^{(53)}$, as well as visual evoked potential (VEPs) at 1 year old (50 weeks), and 66 weeks post-conceptional age ${ }^{(30)}$, although no differences between supplemented and placebo groups were reported. Other studies also reported improved visual acuity (Teller cards) at 4 months but not at 6 months ${ }^{(54)}$, and even improved eye-hand co-ordination at the age of 2.5 years ${ }^{(55)}$. In this line, Judge et al. pointed to a benefit for problem-solving skills but not for recognition memory at 9 months of age ${ }^{(56)}$. Problem solving requires that an infant both remember that a toy is hidden and be able to pay sufficient attention to execute a series of steps to achieve a goal. This result complemented the report of improved mental processing at 4 years ${ }^{(50)}$. Some authors did not find improvements of neurodevelopmental tests as a result of HA supplementation versus placebo during gestation ${ }^{(57,58)}$, but regression analyses showed maternal DHA percentages positively related to measurements of central nervous system development in these studies. In the DOMINO study, no effect of DHA treatment during pregnancy on early childhood cognitive or language scores was reported; fewer children in the DHA treated group had delayed cognitive development compared with the control group, and girls exposed to higher-dose DHA in utero had lower 
language scores than girls from the control group ${ }^{(34)}$, pointing to an interaction with the sex of the children. It has been suggested that the effects of n-3 fatty acids on neurodevelopment might meet a saturation point, above which no further effect of LCPUFA n-3 could be detected ${ }^{(21)}$.

Observational longitudinal studies have also supported a relationship between DHA status and infant development; in Inuits from Arctic Quebec, cord DHA levels were associated with greater visual, cognitive and motor development during the first year of life ${ }^{(59)}$, as well as shorter latencies of VEP in school-age children ${ }^{(60)}$. Further support for the importance of DHA availability in early life comes from the positive associations between maternal fish consumption during pregnancy and cognitive performance of the offspring, observed in large birth cohorts such as ALSPAC ${ }^{(61)}$, VIVA ${ }^{(62)}$ and the Danish National Birth Cohort ${ }^{(63)}$. However, these results should be interpreted with caution, considering the limitations of observational studies which often cannot fully adjust for all confounding variables.

A novel approach has been proposed to check whether a poor DHA status sufficient to delay infant development occurs among pregnant women. In this sense, an increased risk of low visual acuity scores among infants at 2 months of age born to mothers following their usual diet was reported compared with infants of women considered at low risk of inadequate DHA due to DHA supplementation ${ }^{(21)}$. Some pregnant women seem to be DHA-deficient and further studies should addressed to ascertain the dietary n-3 LCPUFA requirements during pregnancy, identificatying the asymptote in functions above which no further benefits occurs.

\section{Effects on maternal depression and infant immunity}

The effect of DHA supplementation during pregnancy on maternal depression has been addressed in very few studies, most of them with a small sample size, possibly non-specific and without placebo comparison. No clear benefit was observed in these studies. Four of these studies did not find significant effect of DHA supplementation taken for 6 or 8 weeks during pregnancy in subjects with diagnosed major depression in studies involving a small number of participants ${ }^{(64-67)}$. Only Su et al. ${ }^{(68)}$ with 36 depressed subjects receiving $1.2 \mathrm{~g}$ $\mathrm{DHA}+2 \cdot 2 \mathrm{~g}$ EPA found reduced depression scores, although no placebo group was included in this study.

In healthy pregnant women, no effect on postpartum maternal depression was found in a study with a small number of subjects ${ }^{(69)}$, or in a large study (DOMINO study) involving more than 2000 participants ${ }^{(34)}$. Recently, Jans et al. ${ }^{(70)}$ performed a meta-analysis including 7 randomized controlled trials, in which a total of 309 women taken n-3 fatty acid supplementation were compared with 303 women following a placebo treatment, and no significant effect was found on post-treatment maternal depression (95\% CI $-0 \cdot 18,0 \cdot 13 ; P=0 \cdot 76$ ). The quality of research in this area needs to be improved.

Concerning the effect of n-3 LCPUFA supplementation in healthy pregnancies and on the immunological function, positive effects were reported concerning a reduction in food allergy risk and Ig E associated eczema in infants during the first year of life ${ }^{(71)}$, and reduced proinflammatory cytokines and Th2 promoting prostaglandin E2 in the mother ${ }^{(72)}$. These results were also supported by Krauss-Etschmann et al. ${ }^{(73)}$, who observed reduced Th2 inflammatory cytokines in cord blood during the NUHEAL study. From the Danish cohort, a lower rate of allergic asthma was observed in 16 year old children born to mothers receiving supplementation with fish oil compared with olive oil ${ }^{(74)}$. For infants with a family history of allergic disease, maternal n-3 LCPUFA supplementation during pregnancy also decreased the risk of food allergy and Ig E eczema during the first year of life $^{(71,75)}$ and improved the cord blood cytokine pattern ${ }^{(76,77)}$.

In conclusion, n-3 LCPUFA supplementation during pregnancy has a moderate effect on higher length of gestation and birth weight, but not enough for general recommendation in order to avoid preterm deliveries. Most of the papers found significant differences in some visual or cognitive tests in the offspring or, at least, positive associations between DHA status in the neonate and pregnant mother and neurodevelopmental outcomes. LCPUFA supplementation, in addition to an already adequate omnivorous diet, may not yield any measurable benefit, but very low LC-PUFA intakes could result in loss of function that could even be of major importance in prematurely born babies. The effect of n-3 LCPUFA supplementation during pregnancy on depressive symptoms has been evaluated in studies with too many limitations to achieve a final conclusion, although no effect was observed in these preliminary studies. In contrast, its effects on reducing allergic biomarkers in children seem very promising.

\section{Acknowledgements}

EL and AGS evaluated the concordance and discrepancy of the bibliographical search. MTPS and BK wrote the manuscript together with EL and AGS. None of the authors was affiliated to any advisory board and or had no financial or personal interests in any organization sponsoring the research.

This research line has received partial financial support from the Paediatric Nutrition Research Award 2009 from European Society of Paediatric Gastroenterology, Hepatology and Nutrition (ESPGHAN). Additional support from Hero Institute for Infant Nutrition, Hero Spain S.A. is gratefully acknowledged. BK is the recipient of a Freedom to Discover Award of the Bristol-Myers-Squibb Foundation, New York, NY, USA.

\section{References}

1. Boyd EM (1934) The lipemia of pregnancy. J Clin Invest 13, 347-363.

2. Peters JP, Heinemann M \& Man EB (1951) The lipids of serum in pregnancy. J Clin Invest 30, 388-394.

3. Al MD, van Houwelingen AC, Kester AD, Hasaart TH, de Jong AE \& Hornstra G (1995) Maternal essential fatty acid patterns during normal pregnancy and their relationship to the neonatal essential fatty acid status. Br J Nutr 74, 55-68.

4. Al MD, van Houwelingen AC \& Hornstra G (2000) Longchain polyunsaturated fatty acids, pregnancy, and pregnancy outcome. Am J Clin Nutr 71, 285S-291S.

5. Stewart F, Rodie VA, Ramsay JE, Greer IA, Freeman DJ \& Meyer BJ (2007) Longitudinal assessment of erythrocyte 
fatty acid composition throughout pregnancy and post partum. Lipids 42, 335-344.

6. Haggarty P (2004) Effect of placental function on fatty acid requirements during pregnancy. Eur J Clin Nutr 58, $1559-1570$.

7. Matorras R, Ruiz JI, Perteagudo L, Barbazan MJ, Diaz A, Valladolid A \& Sanjurjo P (2001) Longitudinal study of fatty acids in plasma and erythrocyte phospholipids during pregnancy. J Perinat Med 29, 293-297.

8. Montgomery C, Speake BK, Cameron A, Sattar N \& Weaver LT (2003) Maternal docosahexaenoic acid supplementation and fetal accretion. Br J Nutr 90, 135-145.

9. Otto SJ, Houwelingen AC, Antal M, Manninen A, Godfrey K, Lopez-Jaramillo P \& Hornstra G (1997) Maternal and neonatal essential fatty acid status in phospholipids: an international comparative study. Eur J Clin Nutr 51, 232-242.

10. Clandinin MT, Chappell JE, Leong S, Heim T, Swyer PR \& Chance GW (1980) Intrauterine fatty acid accretion rates in human brain: implications for fatty acid requirements. Early Hum Dev 4, 121-129.

11. Clandinin MT, Chappell JE, Heim T, Swyer PR \& Chance GW (1981) Fatty acid utilization in perinatal de novo synthesis of tissues. Early Hum Dev 5, 355-366.

12. Campbell FM, Gordon MJ \& Dutta-Roy AK (1996) Preferential uptake of long chain polyunsaturated fatty acids by isolated human placental membranes. Mol Cell Biochem 155, 77-83.

13. Campbell FM, Clohessy AM, Gordon MJ, Page KR \& DuttaRoy AK (1997) Uptake of long chain fatty acids by human placental choriocarcinoma (BeWo) cells: role of plasma membrane fatty acid-binding protein. J Lipid Res 38, 2558-2568.

14. Campbell FM, Gordon MJ \& Dutta-Roy AK (1998) Placental membrane fatty acid-binding protein preferentially binds arachidonic and docosahexaenoic acids. Life Sci $\mathbf{6 3}$, 235-240.

15. Crawford M (2000) Placental delivery of arachidonic and docosahexaenoic acids: implications for the lipid nutrition of preterm infants. Am J Clin Nutr 71, 275S-284S.

16. Gil-Sanchez A, Larque E, Demmelmair H, Acien MI, Faber FL, Parrilla JJ \& Koletzko B (2010) Maternal-fetal in vivo transfer of [13C]docosahexaenoic and other fatty acids across the human placenta $12 \mathrm{~h}$ after maternal oral intake. Am J Clin Nutr 92, 115-122.

17. Haggarty P, Page K, Abramovich DR, Ashton J \& Brown D (1997) Long-chain polyunsaturated fatty acid transport across the perfused human placenta. Placenta 18, 635-642.

18. Larque E, Demmelmair H, Berger B, Hasbargen U \& Koletzko B (2003) In vivo investigation of the placental transfer of (13)C-labeled fatty acids in humans. J Lipid Res 44, 49-55.

19. Chambaz J, Ravel D, Manier MC, Pepin D, Mulliez N \& Bereziat G (1985) Essential fatty acids interconversion in the human fetal liver. Biol Neonate 47, 136-140.

20. Szitanyi P, Koletzko B, Mydlilova A \& Demmelmair H (1999) Metabolism of 13C-labeled linoleic acid in newborn infants during the first week of life. Pediatr Res 45, 669-673.

21. Innis SM \& Friesen RW (2008) Essential n-3 fatty acids in pregnant women and early visual acuity maturation in term infants. Am J Clin Nutr 87, 548-557.

22. Bergmann RL, Haschke-Becher E, Klassen-Wigger P, Bergmann KE, Richter R, Dudenhausen JW, Grathwohl D \& Haschke F (2008) Supplementation with $200 \mathrm{mg} /$ day docosahexaenoic acid from mid-pregnancy through lactation improves the docosahexaenoic acid status of mothers with a habitually low fish intake and of their infants. Ann Nutr Metab 52, 157-166.

23. De V Sr, Matthys C, De HS, De BG, Dhont M \& Christophe $\mathrm{AB}$ (2002) Maternal and umbilical fatty acid status in relation to maternal diet. Prostaglandins Leukot Essent Fatty Acids 67, 389-396.

24. Decsi T \& Koletzko B (2005) N-3 fatty acids and pregnancy outcomes. Curr Opin Clin Nutr Metab Care 8, 161-166.

25. Dunstan JA, Mori TA, Barden A, Beilin LJ, Holt PG, Calder PC, Taylor AL \& Prescott SL (2004) Effects of n-3 polyunsaturated fatty acid supplementation in pregnancy on maternal and fetal erythrocyte fatty acid composition. Eur J Clin Nutr 58, 429-437.

26. Helland IB, Saugstad OD, Saarem K, van Houwelingen AC, Nylander G \& Drevon CA (2006) Supplementation of $n-3$ fatty acids during pregnancy and lactation reduces maternal plasma lipid levels and provides DHA to the infants. J Matern Fetal Neonatal Med 19, 397-406.

27. Krauss-Etschmann S, Shadid R, Campoy C, et al. (2007) Effects of fish-oil and folate supplementation of pregnant women on maternal and fetal plasma concentrations of docosahexaenoic acid and eicosapentaenoic acid: a European randomized multicenter trial. Am J Clin Nutr 85, 1392-1400.

28. Matorras R, Perteagudo L \& Sanjurjo P (1998) Biochemical markers of n-3 long chain polyunsaturated fatty acid intake during pregnancy. Clin Exp Obstet Gynecol 25, 135-138.

29. Parra MS, Schnaas L, Meydani M, Perroni E, Martinez S \& Romieu I (2002) Erythrocyte cell membrane phospholipid levels compared against reported dietary intakes of polyunsaturated fatty acids in pregnant Mexican women. Public Health Nutr 5, 931-937.

30. Malcolm CA, McCulloch DL, Montgomery C, Shepherd A \& Weaver LT (2003) Maternal docosahexaenoic acid supplementation during pregnancy and visual evoked potential development in term infants: a double blind, prospective, randomised trial. Arch Dis Child Fetal Neonatal Ed 88, F383-F390.

31. Barden AE, Dunstan JA, Beilin LJ, Prescott SL \& Mori TA (2006) $\mathrm{n}-3$ fatty acid supplementation during pregnancy in women with allergic disease: effects on blood pressure, and maternal and fetal lipids. Clin Sci (Lond) 111, 289-294.

32. Salvig JD, Olsen SF \& Secher NJ (1996) Effects of fish oil supplementation in late pregnancy on blood pressure: a randomised controlled trial. Br J Obstet Gynaecol 103, 529-533.

33. Koletzko B, Cetin I \& Brenna JT (2007) Dietary fat intakes for pregnant and lactating women. BrJ Nutr 98, 873-877.

34. Makrides M, Gibson RA, McPhee AJ, Yelland L, Quinlivan J \& Ryan P (2010) Effect of DHA supplementation during pregnancy on maternal depression and neurodevelopment of young children: a randomized controlled trial. JAMA 304, 1675-1683.

35. Ramakrishnan $\mathrm{U}$, Stein $\mathrm{AD}$, Parra-Cabrera $\mathrm{S}$, Wang $\mathrm{M}$, Imhoff-Kunsch B, Juarez-Marquez S, Rivera J \& Martorell R (2010) Effects of docosahexaenoic acid supplementation during pregnancy on gestational age and size at birth: randomized, double-blind, placebo-controlled trial in Mexico. Food Nutr Bull 31, S108-S116.

36. Olsen SF, Sorensen JD, Secher NJ, Hedegaard M, Henriksen TB, Hansen HS \& Grant A (1992) Randomised controlled trial of effect of fish-oil supplementation on pregnancy duration. Lancet 339, 1003-1007.

37. Helland IB, Saugstad OD, Smith L, Saarem K, Solvoll K, Ganes T \& Drevon CA (2001) Similar effects on infants of n-3 and n- 6 fatty acids supplementation to pregnant and lactating women. Pediatrics 108, E82. 
38. Knudsen VK, Hansen HS, Osterdal ML, Mikkelsen TB, Mu H \& Olsen SF (2006) Fish oil in various doses or flax oil in pregnancy and timing of spontaneous delivery: a randomised controlled trial. BJOG 113, 536-543.

39. Smuts CM, Huang M, Mundy D, Plasse T, Major S \& Carlson SE (2003) A randomized trial of docosahexaenoic acid supplementation during the third trimester of pregnancy. Obstet Gynecol 101, 469-479.

40. Makrides M, Duley L \& Olsen SF (2006) Marine oil, and other prostaglandin precursor, supplementation for pregnancy uncomplicated by pre-eclampsia or intrauterine growth restriction. Cochrane Database Syst Rev 3, CD003402.

41. Szajewska H, Horvath A \& Koletzko B (2006) Effect of n-3 long-chain polyunsaturated fatty acid supplementation of women with low-risk pregnancies on pregnancy outcomes and growth measures at birth: a meta-analysis of randomized controlled trials. Am J Clin Nutr 83, 1337-1344.

42. Salvig JD \& Lamont RF (2011) Evidence regarding an effect of marine n-3 fatty acids on preterm birth: a systematic review and meta-analysis. Acta Obstet Gynecol Scand 90, 825-838.44.

43. Olsen SF, Secher NJ, Tabor A, Weber T, Walker JJ \& Gluud C (2000) Randomised clinical trials of fish oil supplementation in high risk pregnancies. Fish Oil Trials In Pregnancy (FOTIP) Team. BJOG 107, 382-395.

44. Olsen SF \& Secher NJ (2002) Low consumption of seafood in early pregnancy as a risk factor for preterm delivery: prospective cohort study. BMJ 324, 447.

45. Harper M, Thom E, Klebanoff MA, et al. (2010) Omega-3 fatty acid supplementation to prevent recurrent preterm birth: a randomized controlled trial. Obstet Gynecol 115, $234-242$.

46. Horvath A, Koletzko B \& Szajewska H (2007) Effect of supplementation of women in high-risk pregnancies with long-chain polyunsaturated fatty acids on pregnancy outcomes and growth measures at birth: a meta-analysis of randomized controlled trials. Br J Nutr 98, 253-259.

47. Simmer K, Patole SK \& Rao SC (2008) Longchain polyunsaturated fatty acid supplementation in infants born at term. Cochrane Database Syst Rev 23, 1, CD000376.

48. Schulzke SM, Patole SK \& Simmer K (2011) Longchain polyunsaturated fatty acid supplementation in preterm infants. Cochrane Database Syst Rev 16, 2, CD000375.

49. Fagan JF \& Shephard A (1991) The Fagan Test of Intelligence manual. Cleveland: $\mathrm{OH}$ : Infantest Corporation.

50. Helland IB, Smith L, Saarem K, Saugstad OD \& Drevon CA (2003) Maternal supplementation with very-long-chain $n-3$ fatty acids during pregnancy and lactation augments children's IQ at 4 years of age. Pediatrics 111, e39-e44.

51. Helland IB, Smith L, Blomen B, Saarem K, Saugstad OD \& Drevon CA (2008) Effect of supplementing pregnant and lactating mothers with $n-3$ very-long-chain fatty acids on children's IQ and body mass index at 7 years of age. Pediatrics 122, e472-e479.

52. Colombo J (2001) The development of visual attention in infancy. Annu Rev Psychol 52, 337-367.

53. Malcolm CA, Hamilton R, McCulloch DL, Montgomery C \& Weaver LT (2003) Scotopic electroretinogram in term infants born of mothers supplemented with docosahexaenoic acid during pregnancy. Invest Ophthalmol Vis Sci 44, 3685-3691.

54. Judge MP, Harel O \& Lammi-Keefe CJ (2007) A docosahexaenoic acid-functional food during pregnancy benefits infant visual acuity at four but not six months of age. Lipids $\mathbf{4 2}$, 117-122.

55. Dunstan JA, Simmer K, Dixon G \& Prescott SL (2008) Cognitive assessment of children at age 2(1/2) years after maternal fish oil supplementation in pregnancy: a randomised controlled trial. Arch Dis Child Fetal Neonatal Ed 93, F45-F50.

56. Judge MP, Harel O \& Lammi-Keefe CJ (2007) Maternal consumption of a docosahexaenoic acid-containing functional food during pregnancy: benefit for infant performance on problem-solving but not on recognition memory tasks at age 9 mo. Am J Clin Nutr 85, 1572-1577.

57. Colombo J, Kannass KN, Shaddy DJ, Kundurthi S, Maikranz JM, Anderson CJ, Blaga OM \& Carlson SE (2004) Maternal DHA and the development of attention in infancy and toddlerhood. Child Dev 75, 1254-1267.

58. Tofail F, Kabir I, Hamadani JD, Chowdhury F, Yesmin S, Mehreen F \& Huda SN (2006) Supplementation of fish-oil and soy-oil during pregnancy and psychomotor development of infants. J Health Popul Nutr 24, 48-56.

59. Jacobson JL, Jacobson SW, Muckle G, Kaplan-Estrin M, Ayotte P \& Dewailly E (2008) Beneficial effects of a polyunsaturated fatty acid on infant development: evidence from the inuit of arctic Quebec. J Pediatr 152, 356-364.

60. Jacques C, Levy E, Muckle G, Jacobson SW, Bastien C, Dewailly E, Ayotte P, Jacobson JL \& Saint-Amour D (2011) Long-term effects of prenatal omega-3 fatty acid intake on visual function in school-age children. $J$ Pediatr $\mathbf{1 5 8}$ $83-90,90$.

61. Hibbeln JR, Davis JM, Steer C, Emmett P, Rogers I, Williams C \& Golding J (2007) Maternal seafood consumption in pregnancy and neurodevelopmental outcomes in childhood (ALSPAC study): an observational cohort study. Lancet 369 $578-585$.

62. Oken E, Wright RO, Kleinman KP, Bellinger D, Amarasiriwardena CJ, Hu H, Rich-Edwards JW \& Gillman MW (2005) Maternal fish consumption, hair mercury, and infant cognition in a U.S. Cohort. Environ Health Perspect 113, $1376-1380$.

63. Oken E, Osterdal ML, Gillman MW, Knudsen VK, Halldorsson TI, Strom M, Bellinger DC, Hadders-Algra M, Michaelsen KF \& Olsen SF (2008) Associations of maternal fish intake during pregnancy and breastfeeding duration with attainment of developmental milestones in early childhood: a study from the Danish National Birth Cohort. Am J Clin Nutr 88, 789-796.

64. Freeman MP, Hibbeln JR, Wisner KL, Brumbach BH, Watchman M \& Gelenberg AJ (2006) Randomized dose-ranging pilot trial of omega-3 fatty acids for postpartum depression. Acta Psychiatr Scand 113, 31-35.

65. Freeman MP, Davis M, Sinha P, Wisner KL, Hibbeln JR \& Gelenberg AJ (2008) Omega-3 fatty acids and supportive psychotherapy for perinatal depression: a randomized placebo-controlled study. J Affect Disord 110, 142-148.

66. Freeman MP \& Davis MF (2010) Supportive psychotherapy for perinatal depression: preliminary data for adherence and response. Depress Anxiety 27, 39-45.

67. Rees AM, Austin MP \& Parker GB (2008) Omega-3 fatty acids as a treatment for perinatal depression: randomized doubleblind placebo-controlled trial. Aust N Z J Psychiatry 42 , 199-205.

68. Su KP, Huang SY, Chiu TH, Huang KC, Huang CL, Chang HC \& Pariante CM (2008) Omega-3 fatty acids for major depressive disorder during pregnancy: results from a randomized, double-blind, placebo-controlled trial. J Clin Psychiatry 69, 644-651.

69. Doornbos B, van Goor SA, jck-Brouwer DA, Schaafsma A, Korf J \& Muskiet FA (2009) Supplementation of a low dose of DHA or DHA + AA does not prevent peripartum depressive symptoms in a small population based sample. Prog Neuropsychopharmacol Biol Psychiatry 33, 49-52. 
70. Jans LA, Giltay EJ \& Van der Does AJ (2010) The efficacy of n-3 fatty acids DHA and EPA (fish oil) for perinatal depression. Br J Nutr 104, 1577-1585.

71. Furuhjelm C, Warstedt K, Larsson J, Fredriksson M, Bottcher MF, Falth-Magnusson K \& Duchen K (2009) Fish oil supplementation in pregnancy and lactation may decrease the risk of infant allergy. Acta Paediatr 98, 1461-1467.

72. Warstedt K, Furuhjelm C, Duchen K, Falth-Magnusson K \& Fageras M (2009) The effects of omega-3 fatty acid supplementation in pregnancy on maternal eicosanoid, cytokine, and chemokine secretion. Pediatr Res 66, 212-217.

73. Krauss-Etschmann S, Hartl D, Rzehak P, et al. (2008) Decreased cord blood IL-4, IL-13, and CCR 4 and increased TGF-beta levels after fish oil supplementation of pregnant women. J Allergy Clin Immunol 121, 464-470.

74. Olsen SF, Osterdal ML, Salvig JD, Mortensen LM, Rytter D, Secher NJ \& Henriksen TB (2008) Fish oil intake compared with olive oil intake in late pregnancy and asthma in the offspring: 16 y of registry-based follow-up from a randomized controlled trial. Am J Clin Nutr 88, 167-175.

75. Furuhjelm C, Warstedt K, Fageras M, Falth-Magnusson K, Larsson J, Fredriksson M \& Duchen K (2011) Allergic disease in infants up to $2 \mathrm{yr}$ of age in relation to plasma omega-3 fatty acids and maternal fish oil supplementation in pregnancy and lactation. Pediatr Allergy Immunol.

76. Dunstan JA, Mori TA, Barden A, Beilin LJ, Taylor AL, Holt PG \& Prescott SL (2003) Fish oil supplementation in pregnancy modifies neonatal allergen-specific immune responses and clinical outcomes in infants at high risk of atopy: a randomized, controlled trial. J Allergy Clin Immunol 112, 1178-1184.

77. Dunstan JA, Mori TA, Barden A, Beilin LJ, Taylor AL, Holt PG \& Prescott SL (2003) Maternal fish oil supplementation in pregnancy reduces interleukin-13 levels in cord blood of infants at high risk of atopy. Clin Exp Allergy 33, 442-448.

78. Stein AD, Wang M, Martorell R, Neufeld LM, Flores-Ayala R, Rivera JA \& Ramakrishnan U (2011) Growth to age 18 months following prenatal supplementation with docosahexaenoic acid differs by maternal gravidity in Mexico. J Nutr 141, 316-320.

79. Lucia BR, Bergmann KE, Haschke-Becher E, Richter R, Dudenhausen JW, Barclay D \& Haschke F (2007) Does maternal docosahexaenoic acid supplementation during pregnancy and lactation lower BMI in late infancy? J Perinat Med 35, 295-300. 